Illinois State University

ISU ReD: Research and eData

Faculty Publications-Languages, Literatures, and Cultures

2017

\title{
Communicative Learning Outcomes and World Language edTPA: Characteristics of High-scoring Portfolios
}

\author{
Peter Swanson \\ Georgia State University
}

Susan A. Hildebrandt

Illinois State University, shildeb@ilstu.edu

Follow this and additional works at: https://ir.library.illinoisstate.edu/fpllc

\section{Recommended Citation}

Swanson, Peter and Hildebrandt, Susan A., "Communicative Learning Outcomes and World Language edTPA: Characteristics of High-scoring Portfolios" (2017). Faculty Publications-Languages, Literatures, and Cultures. 68.

https://ir.library.illinoisstate.edu/fpllc/68

This Article is brought to you for free and open access by the Languages, Literatures, and Cultures at ISU ReD: Research and eData. It has been accepted for inclusion in Faculty Publications-Languages, Literatures, and Cultures by an authorized administrator of ISU ReD: Research and eData. For more information, please contact ISUReD@ilstu.edu. 


\section{PROJECT MUSE}

Communicative Learning Outcomes and World Language edTPA:

Characteristics of High-scoring Portfolios

Pete Swanson, Susan A. Hildebrandt

Hispania, Volume 100, Number 3, September 2017, pp. 331-347 (Article)

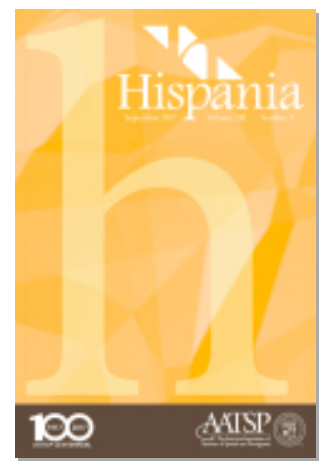

Published by Johns Hopkins University Press

DOI: https://doi.org/10.1353/hpn.2017.0062

$\Rightarrow$ For additional information about this article https://muse.jhu.edu/article/670535 


\section{Communicative Learning Outcomes and World Language edTPA: Characteristics of High-scoring Portfolios}
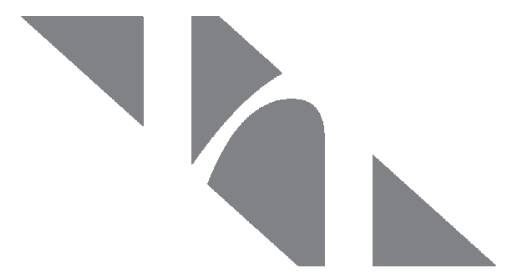

Pete Swanson

Georgia State University

United States Air Force Academy

\author{
Susan A. Hildebrandt \\ Illinois State University
}

\begin{abstract}
Teacher accountability continues to be at the forefront of educational policy in the United States, with the current focus on the Outcomes of K-12 teaching and teacher education (Cochran-Smith 2000). edTPA, a high-stakes assessment used in many states to make licensure or certification decisions, purports to measure those content-specific outcomes. This study investigated pre-service Spanish teachers' performance on the World Language edTPA as it relates to planning for instruction in a communicative context. Specifically, the five highest scoring edTPA portfolios from two large world language teacher education programs were examined, with a focus on their alignment with communicative language teaching approaches and Gronlund's (2004) criteria for articulating student learning outcomes. Results showed serious discrepancies among the candidates' learning outcomes, communicative language teaching approaches, and the spirit of the World Language edTPA. This research has implications for teacher preparation and professional development of beginning language teachers.
\end{abstract}

Keywords: backward design/diseño de atrás hacia adelante, edTPA, learning objectives/objetivos de aprendizaje, teacher evaluation/evaluación docente, teacher preparation/preparación del profesorado

\title{
1. Introduction
}

7 he past several decades of American teacher education reform have highlighted four major questions about teachers: attributes, effectiveness, knowledge, and outcomes (Cochran-Smith 2000). Cochran-Smith (2000) contends that many factors helped shape these questions, including the public's attention to K-12 education and its perceptions of teachers as professionals, the supply of and demand for teachers, and political climate, including state and federal educational funding policies. The most recent focus of teacher educational policy is the Outcomes question, which addresses "teacher learning, professional practice, and student learning" by asking "how, by whom, and for what purposes should these outcomes be documented, demonstrated, and/or measured" (Cochran-Smith 2000: 330).

The most critical result of teacher education, according to the Outcomes question, is student learning. With current reform efforts, student learning outcomes and their measurement determine how successful (or unsuccessful) teacher candidates, their students, teacher education programs, and institutions that prepare teachers are (Cochran-Smith 2000). Earlier questions of teachers and teacher education used measures of teacher knowledge and skills, records of teacher education program inputs (e.g., courses taken, curriculum), and the more recent assessments of teacher effectiveness, which is notoriously difficult to define (Muijs 2006). Showing student knowledge development undergirds educational reform efforts across the world, and providing 
evidence of growth has become central to discussions of individual teacher and teacher education effectiveness (Dale 2014).

One endeavor to examine new teachers' impact on student learning is a high-stakes teacher performance assessment known as edTPA-a subject-specific portfolio that requires teacher candidates to align instruction and assessment with stated student learning objectives. edTPA handbooks define learning objectives as "[s]tudent learning outcomes to be achieved by the end of the lesson or learning segment" (Stanford Center for Assessment, Learning, and Equity, SCALE 2016a: 47). edTPA is used in 747 teacher education programs across 40 states and the District of Columbia (American Association for Colleges of Teacher Education, AACTE n.d.), including several states that require the $\$ 300$ assessment for state licensure or certification. edTPA's subject specificity, widespread usage, high-stakes nature, and focus on learning objectives prompt the present investigation. Given its widespread usage across the country, the World Language (WL) edTPA remains understudied despite recent investigations of the topic (e.g., Behney 2016; Hildebrandt and Swanson 2016; Kissau and Algozzine 2017; Russell and Davidson Devall 2016; Troyan and Kaplan 2015).

\section{Literature Review}

Given the recent focus on the Outcomes question, it is impossible to determine precisely who and what influence teacher candidate performance, either within teacher education programs or outside of them, and to what degree. Within programs, methods classes generally address professionally agreed upon WL teaching practices, including backwards design and communicative language teaching principles. Outside of methods classes, previous language learning experiences, cooperating teachers, and clinical settings influence candidate performance, as do measurements like edTPA.

\subsection{Influences from within WL Methods Classes}

A myriad of forces shape WL teacher education programs and coursework composition. Teacher preparation (e.g., American Council on the Teaching of Foreign Languages, ACTFL 2013) and new teacher standards (e.g., Interstate Teacher Assessment and Support Consortium 2002) inform content presented in methods classes and prompt teacher candidates to create units and lessons that put into practice the principles of Backwards Design (Wiggins and McTighe 2005) and Communicative Language Teaching (Nunan 1991). These standards and the accompanying practices inform teachers' lesson plans for K-12 students' communicative proficiency development as the Outcome.

Backwards Design (Wiggins and McTighe 2005) prompts teachers to first determine desired results of learning by stating learning outcomes, then to determine acceptable evidence through design of appropriate formative and summative assessments, and finally to plan learning experiences and instruction. With this approach, teachers must consider the end result of their instruction, specifically what their students will know and be able to do, well before they begin to develop lesson plans (Wiggins and McTighe 2005).

Learning to design instruction and assessments around observable and measurable learning outcomes is critical to student learning (Gronlund 2004) and teacher success on performance measurements of their abilities, like edTPA. In many educational contexts, the objectives serve as a guide to planning, instruction, and assessment, the first steps to backwards design (Wiggins and McTighe 2005). Teachers state their desired results of instruction by creating target learning objectives and outcomes. While some use the terms objective and outcome interchangeably, Gronlund (2004) differentiates between the terms, defining instructional objectives as "intended learning outcomes, that is, in terms of the types of performance students are able to demonstrate at the end of instruction to show that they have learned what was expected of them" (4). 
Objectives are a more general umbrella term for the learning outcomes to be demonstrated by students. Learning outcomes clarify stated instructional objectives, focus in on student performance, and begin with an action verb (Gronlund 2004). Those action verbs, based on Bloom's taxonomy (Bloom, Engelhart, Furst, Hill, and Krathwohl 1956) or the revised taxonomy (Krathwohl 2002), help teachers determine to what degree students have fulfilled instructional expectations. These instructional objectives can play an important role in improving student learning, communicating intended learning outcomes to others, and evaluating instruction (Gronlund 2000).

Contemporary language methods classes should embody the new paradigm of language teaching (Shrum and Glisan 2016), which recognizes students' need for significant levels of meaningful target language communication. Once accepted practices (e.g., teaching in English about the target language, explicitly teaching verb conjugations) have been rethought and the language teaching profession has reached a tipping point-or as what Kuhn (1962) referred to as a scientific revolution-a paradigm shift that subverts existing traditions of practice. The language teaching profession has experienced a number of changes in professional expectations, which could be characterized as a scientific revolution.

That revolution in language teaching, in part, reduced the importance of form and accuracy in language teaching and assessment in favor of language functions (Shrum and Glisan 2016). Form is the more formulaic aspects of language, the more easily measurable details of language learning such as verb conjugations and spelling. Conversely, function focuses on the purposes of the communicative act and the meaning behind the text, such as compare and contrast, persuade, summarize, or predict.

Communicative Language Teaching (CLT) emphasizes function over form and is usually characterized as an approach to teaching rather than as a method of teaching. According to Nunan (1991), CLT has a set of five classroom features:

1. An emphasis on learning to communicate through interaction in the target language.

2. The introduction of authentic texts into the learning situation.

3. The provision of opportunities for learners to focus not only on language but also on the learning process itself.

4. An enhancement of the learner's own personal experiences as important contributing elements to classroom learning.

5. An attempt to link classroom language learning with language activities outside the classroom.

The ACTFL Proficiency Guidelines (2012) and the World-Readiness Standards for Learning Languages (The National Standards Collaborative Board 2015) help teachers put CLT into practice. Those documents conceptualize language teaching and learning in terms of the three modes of communication: interpretive, interpersonal, and presentational. Language teachers frame assessment and instruction within the three modes so that learners have a "roadmap to develop competence to communicate effectively and interact with cultural competence to participate in multilingual communities at home and around the world" (The National Standards Collaborative Board 2015: 11). ACTFL's (2010) position in favor of teachers using $90 \%$ or more target language in the classroom encourages teachers to provide comprehensible input (Krashen 1981), with an emphasis on authentic materials created by native speakers for native speakers. In that way, students interpret naturalistic language as possible and engage in interpersonal and presentational communication to complete linguistic tasks that help develop their communicative proficiency across the three modes.

CLT practices, backwards design, and stating student learning outcomes in advance encourage language teachers to align the desired student learning outcomes with the proper levels of proficiency, as described in the ACTFL Proficiency Guidelines (2012). Sandrock (2010) 
and Clementi and Terrill (2013) outline how teachers can use those proficiency levels to create performance assessments to measure whether the stated learning objectives and outcomes were met. Those performance assessments, in turn, lead teachers to create daily proficiency level-appropriate tasks for language learners to practice carrying out formative communication tasks and assessments.

Criticisms of learning objectives and outcomes, along with their measurement, have been raised. While explaining the history of the educational accountability movement, Hussey and Smith (2002) explained that with the expansion of obligatory education in the 20th century, "[o]paque and woolly ideas about education had to be made precise; what was implicit must be explicit and the subjective intuitions of educators must be replaced with objective, measurable criteria" (222). They went on to explain that educators "needed to be able to specify observable products of the activities of the educators: i.e. learning outcomes" (223) in order to appear objective in their measurement.

Despite the criticisms, stating learning outcomes a priori is a central tenet of contemporary teacher performance assessments like edTPA, which seek to answer the Outcomes question at the state level (AACTE n.d.). Moreover, teacher candidates must include learning outcomes aligned with standards in their lesson plans, assessments, and feedback to students (SCALE 2016a), which plays a critical role in teacher candidates' success on edTPA.

\subsection{External Influences on Teacher Candidate Performance}

Teacher educators hope that the material taught in general and content-specific pedagogical coursework positively impacts teacher candidates, but those forces are not the only ones that influence teacher candidate performance. Language teacher candidates' previous experiences as students and clinical experiences, like student teaching, can influence their later language teaching, as can the assessments used to measure their performance (e.g., edTPA). Despite the recent revolution or paradigm shift in language teaching explored in methods classes, the first language still has a central role in many second language classrooms (Hlas 2016). Even as the profession shifted from a grammar-translation approach (i.e. language as structure) to CLT approaches, which view language as the vehicle (Larsen-Freeman and Tedick 2016), the old paradigm frequently prevails.

Most teacher candidates experience a long apprenticeship of observation (Lortie 1975) as a student in the K-12 educational system, and teachers put into practice the strategies that were most helpful to them as learners, often teaching the way that they were taught (Oleson and Hora 2014). Kennedy (1999) cautioned that if preservice teacher education cannot shift teacher candidates' teaching ideas shaped earlier when they were students, "teachers' own continuing experiences will reinforce them, cementing them even more strongly into their understandings of teaching, and reducing the likelihood that these ideas might ever change" (57). She further cautioned that, even if the shift does take place during university preparation, teacher candidates may acquiesce to their cooperating teachers' style and philosophy, potentially undoing some of the strides made in teacher preparation classes. For example, Siegel and Wissehr (2011:371) documented the tendency of some science teacher candidates to revert to more traditional types of assessments than those explored in their teacher preparation coursework.

Cooperating teachers' impact on teacher candidate performance is not limited to classroom teaching. Behney (2016) explored mentor teachers' and placement settings' influences on WL teacher candidate edTPA performance, finding that cooperating teachers "modeled a more grammar-based approach than what [student teachers] had been taught to use in their standardsbased methods classes" and that they "seemed to implicitly equate language learning with students' increasing grammatical knowledge" (283). She also found that cooperating teachers and cooperating teachers "recognized that there were important philosophical and instructional differences concerning 90\% target language use" (283). 
Student teacher performance can also be influenced by the way their teaching performance is assessed. The Outcomes question prioritizes teacher candidates' impact on student learning, and edTPA requires teacher candidates to demonstrate student learning as a result of their instruction through a variety of artifacts, including lesson plans, assessments, and student work samples and accompanying feedback. Teacher candidates must state their intended student learning objectives, aligned with national or local standards (SCALE 2016a), in their lesson plans. In the commentaries that accompany various artifacts, teacher candidates must explain how their students' communicative proficiency development will take place in a meaningful cultural context, using the three modes of communication and focusing on language function over form (SCALE 2016a). Specifically, the terms central to WL edTPA, according to SCALE (2016b), Understanding Rubric Level Progressions, are communicative proficiency, language forms, language functions, meaningful cultural context(s), and modes of communication. In short, teacher candidates must show that they are teaching students to communicate in the target language within the three modes of communication, even when highlighting grammatical structure(s) within a contextual context.

edTPA scorers can come from a variety of backgrounds and may have an unintended influence on edTPA scores. Those in higher education and from PK-12 settings, either currently employed or retired, may score edTPA portfolios (Pearson Technology 2016). All must have expertise in the content of the portfolios they will evaluate, and they need to have either teaching experience at their respective level in the United States, considerable professional development, or a bachelor's degree or higher. Higher education faculty, student teacher supervisors, and program coordinators must also have either 1) experience within the last five years of teaching a content-specific teacher education class, supervise teacher candidates, be involved with edTPA implementation at their school, or 2) provide professional development for teacher candidates or beginning teachers. Those in the PK-12 setting who apply to score edTPA portfolios must be a classroom teacher, a mentor or teaching coach for beginning teachers, a principal or other administrator, or be National Board certified. They must also hold a current teaching license in the content area or be currently National Board certified in the content area. Also, within the last five years, they must have hosted or mentored teacher candidates or beginning teachers in the content area they applying to score (Pearson Technology 2016).

The central nature of instructional objectives, learning outcomes measurement, and CLT in the WL edTPA prompt the current investigation. This study uses evidence from edTPA portfolios created by teacher candidates in two American WL teacher preparation programs to determine how the highest scorers designed and aligned educational objectives to assessments and instruction, with the following research questions:

1. How did participants score on individual WL edTPA rubrics that address learning outcomes?

2. How did participants score on individual WL edTPA rubrics that address language form vs. function?

3. To what degree did stated learning outcomes align with CLT approaches?

4. What modes of communication were represented among the stated learning outcomes?

\section{Methods}

\subsection{Institutional Contexts}

The authors serve as WL teacher education program coordinators at Illinois State University and Georgia State University, as well as the instructors of methods courses taken by participants. Illinois State University is a moderately large public institution with approximately 20,000 located in Normal, Illinois while Georgia State University, located in Atlanta, is a larger public institution 
with approximately 53,000 students after being merged with a two-year public college in the Atlanta metropolitan area by the Georgia Board of Regents. The two teacher education programs are among the largest WL teacher education programs currently in the United States, with a combined enrollment of approximately 110 students. At both institutions, teacher candidates must complete six credit hours of pedagogy coursework in preparation for pre-K-12 WL teaching, as well as courses in technology integration, reading instruction, general foundations of education, and working with diverse students. Coursework and assignments focus on standards-based, proficiency-oriented approaches to instruction and assessment.

At both institutions, teacher candidates are placed in a variety of rural, suburban, and urban pre-K-12 schools for a semester-long student teaching experience. Finally, both universities are state accredited and have earned national recognition from the Council for the Accreditation of Educator Preparation. The two samples were combined to form one dataset, and relatively minor academic differences were noted between the two programs. For example, the program at Georgia State University has a mandatory second language acquisition class and a mandatory technology integration class. The program at Illinois State University threads the aforementioned information throughout the methods courses.

\subsection{Participants}

Following Institutional Review Board approval, researchers selected the top scoring 10\% of edTPA portfolios $(n=5)$ submitted by teacher candidates from the two aforementioned WL teacher education programs from 2013 to $2016(N=53)$. The participants represented teacher candidates from both institutions and their portfolios were assessed by external WL edTPA scorers during the student teaching semester. Each teacher candidate in the two programs takes six credits of methods to teach world languages prior to student teaching. All participants are female; three self-identify as Caucasian, one as Latina, and one as African American. All were enrolled in initial certification preparation programs and taught Spanish. None had earned a graduate degree. Such demographics are representative of the two programs and language teachers in general (Swanson 2008, 2012). Teacher candidates, as part of the portfolio construction process, gained permission from parents/guardians to use their child's work and video images for the official edTPA submission. For the purposes of participant anonymity, each of the participants are referred to as Teacher Candidate 1 (TC1), Teacher Candidate 2 (TC2), and so forth.

\subsection{Instrument}

edTPA is a content-specific portfolio used in 40 states and the District of Columbia (AACTE, n.d.), with many states determining their own edTPA cut scores for the purposes of teacher licensure or certification. The high-stakes teacher assessment consists of three tasks: (1) Planning for Instruction and Assessment, (2) Instructing and Engaging Students in Learning, and (3) Assessing Student Learning. In their portfolio, teacher candidates must describe their teaching context and submit several artifacts to demonstrate their teaching abilities, including all lesson plans, instructional activities, and assessments for a three-to-five day learning segment. Additionally, they must submit in-depth written commentaries for each task, up to two video recordings of their teaching limited to no more than 15 minutes of unedited footage, and feedback to three focal students, one of whom must be "a student with specific learning needs" (SCALE 2015: 8).

Teacher candidates in the present study submitted their edTPA portfolios approximately two-thirds of the way through their student teaching semester to enable scores to be received by graduation. Prior to submitting the portfolio for official scoring, teacher preparation faculty may not edit teacher candidates' official materials prior to submission or offer a critique of the candidate's responses containing specific, alternative responses (SCALE 2016c). External reviewers 
(i.e., WL teachers and teacher-educators), vetted and trained by Pearson Education (Pearson Technology 2016), evaluate the WL edTPA portfolios using 13 five-point Likert-scale rubrics.

The maximum score on WL edTPA (SCALE 2016a) is 65 (13 rubrics each with a maximum score of 5 points each). Because one of WL teaching's central purpose is to develop academic language, those rubrics were eliminated in this and classical languages early in the edTPA development process. Cut scores for WL teacher candidates in Georgia and Illinois at the time of the study are 29 and 31, respectively, with increases to 32 and 33 scheduled for September 2017. Scores for WL teachers in Illinois will further increase by two points in both 2018 and 2019 for a final required cut score of 37.

Six of the 13 WL edTPA rubrics (i.e., Rubrics 1 and 2 in the Planning task and Rubrics 10, 11,12 , and 13 in the Assessment task) include at least one mention of the word objective, with several including it in each of the five levels of the rubric. Three rubrics address the question of form versus function (i.e., Rubric 1 in Planning and Rubrics 6 and 7 in Instruction). Each outlines candidates' levels of knowledge and skills, with general performance for each described as:

Level 1: the knowledge and skills of a struggling candidate who is not ready to teach; Level 2: knowledge and skills of a candidate who is possibly ready to teach;

Level 3: knowledge and skills of a candidate who is ready to teach;

Level 4: solid foundation of knowledge and skills for beginning teacher;

Level 5: advanced skills and abilities of a candidate very well-qualified and ready to teach. (SCALE 2013: 12)

The lower end of the scale describes the performance of someone not yet ready to teach, while the higher end generally describes that of a more skillful candidate.

\subsection{Data Analysis}

Participants' edTPA portfolios were downloaded from LiveText, an online data repository and analysis interface, and the data were de-identified and password-encrypted. Independently, each researcher analyzed participants' lesson plans and rated each stated student learning outcome as either focus on form or communicative. Verbs used in the outcomes were rated as either active and measurable (Gronlund 2004) or not. Researchers eliminated any activity descriptions mislabeled as learning outcomes. Any activity descriptions that outlined steps of what students would do during or after class, as opposed to how learners would demonstrate having met the stated learning outcomes, were eliminated. For example, a learning outcome stated as "[students] will have the opportunity to complete an extracurricular project beyond the classroom" was removed from the data set. This procedure was pilot tested successfully with one high-scoring portfolio (Hildebrandt and Swanson 2016). Objectives determined to be communicative were further categorized according to the mode of communication addressed.

A colleague from one of the two teacher education programs served as a third rater when the researchers' reviews of learning outcomes were not consistent. This reviewer provided an independent rating to reconcile the authors' reviews. Data analysis took place synchronously via Skype and notes were taken using Google Docs. Interrater reliability between the authors was $98 \%$.

\section{Results}

An overall examination of the results shows that the five participants scored well above the cut scores set forth by either state (see Table 1). The participants' final scores ranged from 49 to 60 out of a possible 65 points. Rubrics with at least one mention of objective (Rubrics 1, 2, 10, 11,12 , and 13) and those concerning form vs. function (Rubrics 1, 6, and 7) are highlighted. Thirty-seven of the 40 highlighted rubric scores were scored as either a 4 or a 5 . 


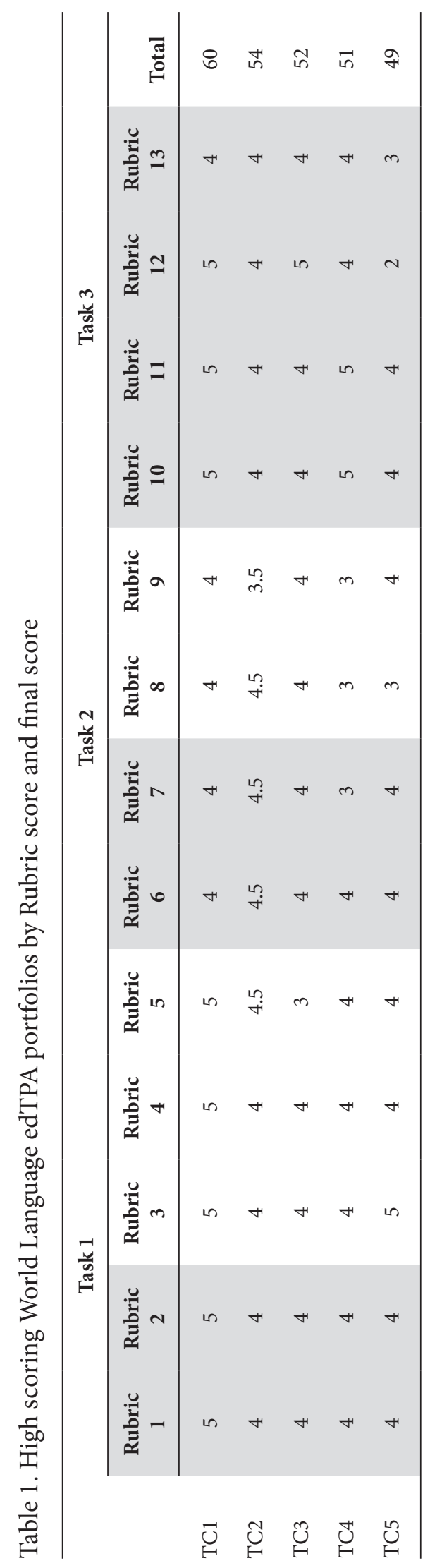


Researchers examined participant scores on Rubrics 1, 2, 10,11, 12, and 13 in order to answer the first research question about scores on WL edTPA rubrics that address learning outcomes. Table 1 shows that the external reviewers scored these rubrics with mostly $4 \mathrm{~s}$ or $5 \mathrm{~s}$ (93\%), indicating that these teacher candidates either have a "solid foundation of knowledge and skills for beginning teacher" (SCALE 2013: 12) or "advanced skills and abilities of a candidate very well-qualified and ready to teach" (12), as indicated by a score of 4 and 5 respectively. The participant who scored 49 of 65 total points, earned a 2 and 3, respectively, on objectives Rubrics 12 and 13.

The second research question inquired how participants scored on rubrics that address language form vs. function (i.e., Rubrics 1, 6, and 7). Table 1 shows that participants earned mostly scores of 4 or 5 on those rubrics, with one exception. The participant scoring 51 total points earned a 3 on Rubric 7 (Deepening Student Communicative Proficiency in the Target Language). Two rubrics from second highest scoring portfolio received scores of 4.5, which means that one of the two external reviewers awarded a 4 and the other awarded a 5 for an average score of 4.5. Such findings suggested that the external reviewers believed that the participants were engaging students in "cooperative language tasks that provide clear connections between language forms and functions of the target language" and "cooperative language tasks that lead students to deepen and extend communicative proficiency in the target language in meaningful cultural context(s)" (SCALE 2016a: 23), as found in Levels 4 and 5 of Rubric 6 (Engaging Students' Target Language Communication), respectively.

The third research question concerned the degree to which stated learning outcomes align with CLT approaches. The participants stated learning outcomes were analyzed by the authors, who also taught the methods courses taken by participants. The highest scoring portfolio, created by TC1 and earning an overall score of 60 , included lesson plans listing 43 outcomes over three consecutive teaching days on block schedule. Of those 43 outcomes, approximately one in three (30\%) were rated as communicative in nature, while about one-quarter $(23 \%)$ of the outcomes were coded as focus on form. Slightly less than half (42\%) were composed using active verbs and approximately one-quarter of the outcomes (26\%) were rated as measureable. TC2 included 14 outcomes in her three 45-minute-long lesson plans. Most were coded as communicative

Table 2. Ratings of teacher candidates' planning outcomes and World Language edTPA total scores

\begin{tabular}{llcccccc}
\hline & Class Time & $\begin{array}{c}\text { Number } \\
\text { of } \\
\text { Outcomes }\end{array}$ & $\begin{array}{c}\text { Number of } \\
\text { Communicative } \\
\text { Outcomes }\end{array}$ & $\begin{array}{c}\text { Number of } \\
\text { Outcomes } \\
\text { Expressed } \\
\text { as Focus } \\
\text { on Form }\end{array}$ & Active & Measureable & $\begin{array}{c}\text { edTPA } \\
\text { Score }\end{array}$ \\
\hline TC1 & 3 block lessons & 43 & 13 & 10 & 18 & 11 & 60 \\
& $@ 90$ minutes & & $(30 \%)$ & $(23 \%)$ & $(42 \%)$ & $(26 \%)$ & \\
TC2 & 3 lessons @ & 14 & 11 & 2 & 11 & 11 & 54 \\
& 45 minutes & & $(79 \%)$ & $(14 \%)$ & $(79 \%)$ & $(79 \%)$ & \\
TC3 & 3 lessons @ & 8 & 1 & 7 & 8 & 8 & 52 \\
& 49 minutes & & $(13 \%)$ & $(87 \%)$ & $(100 \%)$ & $(100 \%)$ & \\
TC4 & 5 lessons @ & 25 & 4 & 6 & 17 & 17 & 51 \\
& 55 minutes & & $(16 \%)$ & $(24 \%)$ & $(68 \%)$ & $(68 \%)$ & \\
TC5 & $\begin{array}{l}2 \text { block lessons } \\
\text { @ 90 minutes } \\
\text { every other day }\end{array}$ & 4 & 1 & 2 & 4 & 4 & 49 \\
\hline
\end{tabular}


(79\%) and two (14\%) as focus on form. The majority of the outcomes were both active (79\%) and measureable (79\%), yet her final edTPA score was six points lower (54 points) than TC1's score. The three lesson plans created by the third participant for a traditionally scheduled class included eight outcomes. Of those outcomes, one was rated as communicative; the remaining $87 \%$ focused on form. All of her outcomes were coded as active and measureable, and she received a score of 52, two points lower than TC2. TC4's lesson plans listed 25 outcomes for five 55-minute class periods, with four (16\%) categorized as communicative and six (24\%) focusing on form. Slightly less than three-quarters of the outcomes (68\%) were coded as active and measureable. With a score of 51, TC4 portfolio scored one point lower than TC3 and three points lower than TC2. The final participant, TC5, taught on a block schedule like TC1 and listed four learning outcomes in her two-day learning segment. Twenty-five percent of those outcomes were coded as communicative and half as focused on form. All of TC4's outcomes were coded active and measureable and the portfolio scored 49, two points fewer than TC4's.

Concrete examples help illustrate the difference between focus on form and communicative stated learning outcomes. Outcomes like the following were coded as focus on form: students will "fill in a paper with the verbs of the "gustar type" (TC1), "recall a poem in order to apply a grammar rule" (TC1), "conjugate reflexive verbs" (TC5), and "explain when and why the subjunctive is used with a partner" (TC3). Some outcomes coded as communicative include: students will "talk to their classmates using the clothing vocabulary learned" (TC4), "identify distinct cultural practices and products of Granada, Barcelona, Madrid, and Malaga by listening to a cultural PowerPoint presentation" (TC2), and "talk about their daily routine" (TC5).

Analysis of the lesson plans showed no pattern in which a teacher would first focus on form (e.g., a specific grammar notion, verb tense) and then develop communicative learning opportunities for students. Several grammar lessons appeared to be inserted without connection to a CLT opportunity in several of the lesson plans. For example, the participant with the highest score in the dataset started the first day of the learning segment with students filling in a worksheet with "gustar type" verbs. Then, learners were to find Granada, Spain on a map and were to "discuss its cultural heritage." Then, they were to navigate a Spanish government webpage and virtually visit an assigned building. Afterwards, they were to share their answers with the whole class before doing an activity in which students were to "practice with their feet and their hands Flamenco rhythms with the TPR activity and the interjection of an excited [sic] approval, "¡Olée" [sic]. Across the participant's stated learning outcomes, there was no mention of specific cultural perspectives, the Spanish webpage, the assigned building, what the topic of the discussion was, or what the TPR activity was. Similar disjointed and poorly sequenced activities, independent of stated learning outcomes, were also found in the other four participants' lesson plans.

The final research question concerns the modes of communication represented in participants' learning outcomes. Table 3 shows the researchers' interpretation of the participants' lesson plans and accompanying materials in terms of the three modes of communication. The interpretive and presentational modes were the addressed over twice as much as the interpersonal in stated learning outcomes. The interpersonal mode was present in approximately $16 \%$

Table 3. Participants' communicative learning outcomes by the three modes of communication

\begin{tabular}{lcccccc}
\hline & TC1 & TC2 & TC3 & TC4 & TC5 & Total \\
\hline Interpretive & 6 & 3 & 0 & 3 & 0 & 12 \\
Interpersonal & 3 & 2 & 0 & 0 & 0 & 5 \\
Presentational & 4 & 6 & 1 & 1 & 1 & 13 \\
\hline
\end{tabular}


of the communicative outcomes. Multiple errors were found in categorizing activities as either interpersonal and presentational, with several planned skits described as interpersonal instead of presentational in accompanying written commentaries for each task.

Overall inspection of rubric scores related to the participants' stated learning outcomes did not yield a noticeable pattern. For example, while four of the five participants' learning outcomes were coded mostly as active and measureable, the final WL edTPA scores for these four participants ranged five points but not in any predictable manner. The lack of pattern was more ambiguous when examining the communicative nature of the outcomes and those focusing on structures of the target language.

\section{Discussion}

The purpose of this research was to explore 1) how teacher candidates with high-scoring edTPA portfolios performed on learning outcomes and form vs. function rubrics; 2) the degree to which the learning outcomes stated in those portfolios align with CLT; and 3) the modes of communication represented. While the WL edTPA remains under researched (Behney 2016; Hildebrandt and Swanson 2016; Kissau and Algozzine 2017; Russell and Davidson Devall 2016; Troyan and Kaplan 2015), this research expands the literature base by examining teacher educators' analyses of edTPA portfolios.

The development of high quality learning opportunities begins with planning. Starting with the end in mind is crucial to effective instruction and to helping students reach higher levels of learning. Effective planning for language learning includes, but is not limited to, setting communicative and measurable learning goals, developing the three modes of communication, and integrating authentic texts. Novice teachers must "think strategically about how their actions within a given practice serve a larger educational and instructional purpose" (Glisan and Donato 2016: 1). Thus, developing observable and measurable learning outcomes is vital to student learning (Gronlund 2004). Well-articulated and sequenced language learner outcomes should focus on student performance in the target language for communicative purposes.

The language teaching profession advocates using the target language for purposes that are as authentic to the learner as possible, and having students actively use the target language to engage in communicative situations with real people is paramount. By beginning with the end in mind (Wiggins and McTighe 2005), TCs can determine authentic tasks and situations to help their students develop communicative proficiency across the modes. The use of performance assessments underlies effective language teaching and can help a TC meet the requirements of an edTPA portfolio. Creating learning objectives and the supporting learning outcomes is a sophisticated endeavor, but teacher candidates may determine their desired results by using simplified verb lists instead of starting with the end in mind. As a result, the outcomes stated by student teachers may not have a proficiency development focus. Simple verb lists can oversimplify, obfuscate, and over- or underestimate students' true cognitive operations carried out during a given task. edTPA rubrics and scoring practices focus on objectives but do not necessarily measure the quality of those learning outcomes.

Over the past several decades, the paradigm of language teaching has shifted from grammartranslation to communicative approaches (Shrum and Glisan 2016). CLT prioritizes language function over form (Long 1996; Nunan 1991), as do WL edTPA rubrics (SCALE 2016a). Teacher candidates in this study's two WL teacher preparation programs learn to teach languages with a standards-based approach, with communication the focus of instruction and assessment. They are taught to plan and deliver instruction whereby students communicate through interaction in the target language across the three modes of communication. Teaching explicit grammar in English and focusing on form are not advocated or investigated in depth; in fact, instructors in these programs encourage teacher candidates to avoid the old paradigm practices with which many of them learned the language that they hope to teach. 
Those within-program influences, however, did not manifest edTPA lesson plans that followed those parameters exclusively. While examples in the participants' lesson plans showed that CTL notions were included (e.g., integrating authentic texts into instruction), there were many examples of non-communicative learner outcomes that lacked active learner participation or even measurable communicative outcomes. For example, the participant with the highest scoring portfolio in the dataset had only $42 \%$ and $26 \%$ of their learning outcomes rated as active and measureable, respectively. Less than one-third of those learning outcomes were expressed in communicative terms. Overall, four of the five participants' lesson plans had less than one-third of their total learning outcomes stated in a communicative fashion, while every lesson plan contained examples of learning outcomes focused on form. The researchers were frequently forced to review accompanying instructional materials and commentaries to discern what the teacher candidates were planning to accomplish during the learning segments. During the data analysis process, it was commonplace to find nebulous learning outcomes that were difficult to decipher or that were activity descriptions, such as students will "have a better understanding of the Flamenco" (TC1) or "demonstrate their vocabulary knowledge of cities by rewriting a dictated paragraph" (TC1). Additionally, modes of communication were frequently misidentified in lesson plans and commentaries.

Nevertheless, the scores assigned to the portfolios by vetted, external reviewers suggest that these portfolios are outstanding examples of high quality planning and highly effective teaching in the WL context. A review of Understanding Rubric Level Progressions (SCALE 2016b) shows that teacher candidates must detail how they plan to organize tasks, activities, and/or materials to align with their students' communicative proficiency in the target language in meaningful cultural context(s). With respect to Rubric 1, Planning for Communicative Proficiency in the Target Language, a median score of 3 indicates that plans for instruction are 1) sequenced to facilitate students' communicative proficiency; 2) built upon one another; and 3) focused on the interpretive and one other mode of communication to connect target language functions and forms (SCALE 2016a). The distinction between scores of a 3 and a 4 is that the plans 1) must show intentional connections between forms and functions focusing on all three modes of communication and that 2) students apply language forms to purposefully communicate in all three modes of communication. For a score of 5, the plans "must include activities and questions that will clearly support students in making these connections themselves" (SCALE 2016a: 5), as well as having learners create meaning and reflect on language forms and functions for authentic communicative purposes.

The data, however, did not support participants' scores of 4 and 5 on Rubric 1. Most lesson plans in the dataset were not logically sequenced, and grammar lessons were inserted haphazardly with newly-learned structures not used for communicative purposes in subsequent activities. In many cases, learners were asked to fill out worksheets that simply practiced the form in a decontextualized manner. Additionally, data analysis found a frequent lack of adherence to CLT principles and misunderstandings of the three modes of communication. For example, an activity that had students develop a conversation and then read it aloud to the class was categorized as interpersonal; the interpersonal mode is for activities that promote spontaneous communication and require negotiation of meaning, an integral part for second language acquisition (Long 1996). It is the presentational domain that allows for rehearsed language.

Such findings were not limited to Rubric 1. A score of 3 on Rubric 6, Engaging Students Target Language Communication, focuses on learners being cooperatively engaged in interpersonal or presentational language tasks in the instructional video(s) submitted for the instruction task (SCALE 2016a). For a score of 4, the learning task must focus on one of those two modes and make apparent the connections between form and function. All participants in this study received scores of 4 , save for one who scored a 4.5. Participants focused heavily on the interpretive and presentational modes of communication, but not on the interpersonal mode. That is, students interpreted and presented rehearsed information, but they were limited in opportunities 
to negotiate meaning actively or exchange information in spontaneous and meaningful ways, conflicting with the central tenets of CLT. Communicative approaches require students to interact in the target language, but analysis of these high-scoring portfolios showed that focus was placed on students' ability to interpret information and present rehearsed and frequently scripted discourse at the expense of the interactional and unpracticed interpersonal interactions. The critical practice of real-life, spontaneous communication was not demonstrated in these portfolios as much as would be expected given the central role of interpersonal communication in the new paradigm of language teaching (The National Standards Collaborative Board 2015).

Similar findings were found with respect to Rubric 7, Deepening Student Communicative Proficiency in the Target Language, which focuses on form vs. function much like Rubric 6. Without having copious and well-sequenced opportunities to have students interact and negotiate meaning in the target language, the development of student communicative proficiency is suspect. Scores of 4, 4.5, 4, 3, and 4 were awarded on Rubric 7. Viewed collectively, such scores suggest that most participants have a "solid foundation of knowledge and skills for beginning teacher" (Level 4) and "advanced skills and abilities of a candidate very well-qualified and ready to teach" (Level 5) (SCALE 2013: 12). However, data analysis indicated otherwise.

This study's findings suggest that external influences played a strong role in the way that participants constructed their edTPA lessons, despite the six credits of methods classes taken prior to student teaching. We theorize that participants returned to the way that they were taught Spanish; that is, in English with decontextualized drills, with students learning about the language instead of using the language for communicative purposes (Krashen 1981). Research shows that teachers tend to teach as they were taught (Britzman 1991; Goodlad 1982; Lortie 1975), which is "influential enough to override the effects of teacher education programs" (McMillan 1985: 85). Further, cooperating teachers can exert a substantial influence on teacher candidate pedagogical practices (Behney 2016; Kennedy 1999), and participants may have felt pressure to acquiesce to a more form-focused approaches to teaching language (Kennedy 1999; Oleson and Hora 2014). The new paradigm explored in their methods classes may have differed from the reality that participants found in their student teaching placements. Further, geographic diversity of student teaching placements and pressures within the schools hosting student teachers make it challenging for the two programs from which participants graduated to find cooperating teachers who consistently put into practice the principles of CLT.

Another external factor that influences rubric scores, we theorize, are edTPA evaluation practices. Despite having scored high on the rubrics that focus on objectives, these high-scoring portfolios demonstrated a lack of ability to formulate communicative learning outcomes for their students. Additionally, a surprising percentage of the stated learning outcomes harkened back to form-focused and grammar-centric outcomes. It seems that edTPA evaluation practices prioritize the presence of planned objectives and their alignment with assessments and instruction over contemporary content-specific pedagogical practices, at least in the case of WL. Data analysis revealed that many of the top-scoring portfolios' learning outcomes neither aligned with the activities described or assessments, although rubric scores indicated otherwise. So many of the learning outcomes were poorly written and did not focus on student communicative proficiency development. The high scores awarded seem to prioritize the mere presence of objectives over their content and quality. Almost all of the participants received scores of 4 and 5 on nearly all of the rubrics we examined, but the data indicated that the learning outcomes were not of such a high quality when viewed through a CLT lens. Despite the content specificity touted by edTPA, it seems that the WL assessment does not represent contemporary WL pedagogical practices.

Evaluation time frames suggested for scorers to review portfolios presents another potential external influence on teacher candidate performance. Evaluators are expected to spend two to three hours per portfolio (Pearson Technology 2016), which includes viewing 15 minutes of videotaped teaching and reviewing all lessons plans, assessments, and teaching materials for the three to five-day learning segment, as well as reading up to 25 pages of commentaries in 
11-point font. The cognitive load required to effectively review that quantity of data seems to surpass that suggested time frame. Paid on a per portfolio basis, it is financially advantageous for scorers to complete as many evaluations as possible and, therefore, they may not devote the time necessary to adequately assess the copious amount of information submitted. While edTPA focuses on learning objectives and outcomes, lesson plans included in this study were frequently so unclear that it is difficult to tell what the teaching candidates were doing from reading their lesson plans alone. We suspect that the lack of clarity left much subjectivity to the reviewers, despite the rubrics in the handbook (SCALE 2016a).

External reviewers' qualifications raise additional concerns. Based on the incongruity found between our analysis and the high scores awarded on the rubrics examined, we suspect discrepancies between current language teaching practices taught in methods classes and what reviewers believe to be effective practice, even as they use edTPA rubrics to score portfolios. Existing scorer pedagogical beliefs may influence their teaching and edTPA scoring practices, even more than the rubric descriptions themselves. Teacher beliefs are pervasive in practice and cannot be underestimated (Hildebrandt and Swanson 2016; Hlas 2016). The inconsistencies reported here and questions posed by WL teacher education faculty members and pre-service and in-service language teachers prompt a request for transparency in the external reviewers hiring practices. Further investigating potential reviewers' classroom practices and philosophy of teaching would help make edTPA scoring practices adhere more closely to the CLT approaches taught during methods classes. At present, external reviewer qualifications remain unclear. Further, training for world language edTPA external reviewers should be framed in CLT approaches, emphasizing communicative learning outcomes.

Additionally, the ongoing world language teacher shortage (Swanson 2012) limits the pool from which scorers can be drawn, both at PK-12 and higher education levels. As an example, in the state in which participants carried out their teacher preparation, teachers of other content areas can earn a language-teaching license if they pass the language-specific state content test, without ever having taken a WL methods class. For instance, someone who majored in English education and passed the content test in Spanish can get a Spanish teaching license and job in a high school, thereby qualifying them to host student teachers and score edTPA portfolios. Since Spanish teachers are in demand and there are fewer English teaching positions, this scenario is rather realistic. The inadequate number of language teachers available suggests a limited number of WL teacher educators from which to draw from to score edTPA portfolios. Small universities' WL teacher preparation programs faculty members, hired to teach literature, culture, or linguistics classes, may be asked to teach the university's one language teacher course per year, even without a background in teacher education. That same faculty member may also be required to supervise student teachers, thereby meeting the scorer qualifications set forth by Pearson Technology (2016), but without necessarily having embraced the paradigm shift to an in-depth knowledge of communicative language teaching approaches (Nunan 1991), such as the modes of communication and how to align learning outcomes to assessments.

Overall, the results from the analysis and the conclusions that we have drawn call into question the assessment of a high stakes test required by many states for teacher licensure. Additionally, they reveal incongruities between edTPA scorers' analysis of high-scoring world language edTPA portfolios and the authors' analysis as teacher-educators. Such a serious claim definitely requires further investigation due to the dearth of studies on the WL edTPA.

\subsection{Limitations and Future Research}

While these findings pose serious questions about the scoring of edTPA, this study is not without its limitations. First, the data were taken from a small number of participants from two WL teacher education programs in the United States, and we recommend replicating this study with a larger number of participants. Second, a number of stated learning outcomes or 
objectives were eliminated from analysis because they did not meet Gronlund's (2004) criteria. In particular, those eliminated objectives frequently described learning activities instead of what students would be able to do as a result of instruction, and their elimination limited the number of learning outcomes included for analysis. Additionally, it would be informative to verify if our supposition that the participants may have reverted to teach as they were taught via qualitative analysis; however, it is outside the scope of the study. Finally, the researchers helped prepare these individuals to become language teachers. They limited bias in their analysis by de-identifying participants' portfolios prior to analysis.

Notwithstanding these limitations, most language teacher preparation programs in the United States are small in numbers of teacher candidates (Swanson 2012). Thus, future research using a qualitative approach to analyze the learning outcomes in the edTPA portfolios prepared by teacher candidates from other programs would be insightful. This exploratory study has examined high-scoring WL edTPA portfolios and how teacher candidates' stated learning outcomes aligned with CLT practices, particularly in regard to form vs. function and modes of communication. Future research exploring stated learning outcomes across other content areas would be informative and help stakeholders have better understanding of how to prepare teacher candidates for this high-stakes assessment. Further investigating the variables that influence teacher candidate edTPA performance, both within and outside of university coursework, would also be of value. Further, connecting teacher candidates with cooperating teachers who put CLT principles into practice is critical, and research-based explorations of that process could improve teacher candidate edTPA success. An exploration of the qualifications and professional experiences of edTPA portfolio evaluators would elucidate the evaluation process and, we believe, make it more transparent.

Despite a new administration in Washington, D.C., teacher education will most likely continue its current focus on learner outcomes (Cochran-Smith 2000). edTPA is a relatively new means of assessing new teacher readiness, but it is already being implemented in 747 teacher education programs, 40 states, and the District of Columbia. As edTPA data are used across the nation to make critical educational decisions, the assessments' wide usage poses serious consequences for teacher candidates, teacher educators, and even teacher-educator programs. We agree that documenting evidence of student growth is central to discussions of individual teacher and teacher education program effectiveness (Dale 2014) and that defining teacher effectiveness is difficult (Muijs 2006).

The misalignment of WL teacher education program expectations and edTPA evaluation practices, as described in this study, call into question edTPA's utility in making decisions related to WL teacher candidate performance. Additionally, its $\$ 300$ price tag adds to the already high expense of becoming a teacher, with newly certified teachers in Georgia paying more than $\$ 800$ for required mandated teacher testing (Hildebrandt and Swanson 2014). There is a dearth of investigations regarding this high-stakes assessment (e.g., Behney 2016; Hildebrandt and Swanson 2016; Russell and Davidson Devall 2016), and we call for further studies documenting its impact on beginning teacher preparation practices and K-12 student learning, along with factors influencing teacher candidate edTPA performance.

\section{WORKS CITED}

American Association for Colleges of Teacher Education. (n.d.). “Participation Map.” Web. 17 Jan. 2017.

American Council on the Teaching of Foreign Languages. (2010). "Use of the Target Language in the Classroom." Web. 12 Jun. 2017.

. (2012). ACTFL Proficiency Guidelines 2012. White Plains: ACTFL. Web. 12 Jun. 2017.

. (2013). ACTFL/CAEP Program Standards for the Preparation of Foreign Language Teachers. Web.

12 Jun. 2017.

Behney, Jennifer. (2016). "Perceived Influence of Cooperating Teachers on edTPA Performance." Foreign Language Annals 49.3: 271-86. Print. 
Bloom, Benjamin. S., Max D. Engelhart, Edward J. Furst, Walker H. Hill, and David R. Krathwohl. (1956). Taxonomy of Educational Objectives: The Classification of Educational Goals. Handbook 1: Cognitive Domain. New York: McKay. Print.

Britzman, Deborah. (1991). Practice Makes Practice: A Critical Study of Learning to Teach. Albany: State U of New York P. Print.

Clementi, Donna, and Laura Terrill. (2013). The Keys to Planning for Learning: Effective Curriculum, Unit, and Lesson Design. Alexandria: ACTFL. Print.

Cochran-Smith, Marilyn. (2000). "The Questions that Drive Reform." Journal of Teacher Education 51: 331-33. Print.

Dale, Roger. (2014). "Globalization, Higher Education, and Teacher Education: A Sociological Approach." Teacher Education in a Transnational World. Ed. Rosa Bruno-Jofré and James Scott Johnston. Toronto, Canada: U of Toronto P. 33-53. Print.

Glisan, Eileen, and Rick Donato. (2016). Enacting the Work of Language Instruction. Alexandria: ACTFL. Print.

Goodlad, John. (1982). “Let's Get on with Reconstruction.” Phi Delta Kappan 64: 19-20. Print.

Gronlund, Norman E. (2004). Writing Instructional Objectives for Teaching and Assessment. Upper Saddle River: Pearson. Print.

Hildebrandt, Susan A., and Pete Swanson. (2014). "World Language Teacher Candidate Performance on edTPA: An Exploratory Study." Foreign Language Annals 47.4: 576-91. Print.

- (2016). Understanding the World Language edTPA: Research-based Policy and Practice. Charlotte: Information Age. Print.

Hlas, Anne C. (2016). “Secondary Teachers' Language Usage: Beliefs and Practices." Hispania 99.2: 305-19. Print.

Hussey, Trevor, and Patrick Smith. (2002). "The Trouble with Learning Outcomes.” Active Learning in Higher Education 3.3: 220-33. Print.

Interstate New Teacher Assessment and Support Consortium. (2002). "Model Standards for Licensing Beginning Foreign Language Teachers: A Resource for State Dialogue." Washington, DC: Council of Chief State School Officers. Print.

Kennedy, Mary M. (1999). “The Role of Preservice Teacher Education.” Teaching as the Learning Profession: Handbook of Teaching and Policy. Ed. Linda Darling-Hammond and Gary Sykes. San Francisco: Jossey Bass. 54-86. Print.

Kissau, Scott, and Bob Algozzine. (2017). "Effective Foreign Language Teaching: Broadening the Concept of Content Knowledge." Foreign Language Annals 50.1: 114-34. Print.

Krashen, Stephen. (1981). Second Language Acquisition and Second Language Learning. Oxford: Pergamon. Print.

Krathwohl, David R. (2002). "A Revision of Bloom's Taxonomy: An Overview." Theory into Practice 41: 212-18. Web. 12 Jun. 2017.

Kuhn, Thomas S. (1962). The Structure of Scientific Revolutions. Chicago: U of Chicago P. Print.

Larsen-Freeman, Diane, and Diane J. Tedick. (2016). "Teaching World Languages: Thinking Differently." Handbook of Research on Teaching. Ed. Drew H. Gitomer and Courtney. A. Bell. Washington, DC: American Educational Research Association. 1335-88. Print.

Long, Michael H. (1996). "The Role of the Linguistic Environment in Second Language Acquisition." Handbook of Research on Language Acquisition: Vol. 2. Second Language Acquisition. Ed. William C. Ritchie and Tej K. Bhatia. New York: Academic. 413-68. Print.

Lortie, Dan C. (1975). Schoolteacher: A Sociological Study. Chicago: U of Chicago P. Print.

McMillan, Catherine. M. (1985). “Do Teachers Teach as They Were Taught to Teach?” American Reading Forum Yearbook 5: 85-87. Print.

Muijs, Daniel. (2006). "Measuring Teacher Effectiveness: Some Methodological Reflections." Educational Research and Evaluation: An International Journal on Theory and Practice. 12: 53-74. Print.

The National Standards Collaborative Board. (2015). World-Readiness Standards for Learning Languages. Alexandria: Author. Print.

Nunan, David. (1991). "Communicative Tasks and the Language Curriculum." TESOL Quarterly 25: 279-95. Print.

Oleson, Amanda, and Matthew T. Hora. (2014). "Teaching the Way They Were Taught? Revisiting the Sources of Teaching Knowledge and the Role of Prior Experience in Shaping Faculty Teaching Practices." Higher Education 68.1: 1-17. Print.

Pearson Technology. (2016). “edTPA Scorer Qualifications.” Web. 12 June 2017. 
Russell, Victoria, and Kelly F. Davidson Devall. (2016). "An Examination of the edTPA Portfolio Assessment and Other Measures of Teacher Preparation and Readiness." Foreign Language Annals 49.4: 479-501. Print.

Sandrock, Paul. (2010). The Keys to Assessing Language Performance. Alexandria: American Council on the Teaching of Foreign Languages. Print.

Shrum, Judith L., and Eileen W. Glisan. (2016). Teacher's Handbook, Contextualized Language Instruction. Boston: Cengage Learning. Print.

Siegel, Marcelle A., and Cathy Wissehr. (2011). "Preparing for the Plunge: Preservice Teachers' Assessment Literacy." Journal of Science Teacher Education 22.4: 371-91. Print.

Stanford Center for Assessment, Learning, and Equity. (2013). "2013 edTPA Field Test: Summary Report." Stanford: Stanford UP. Web. 12 Jun. 2017.

. (2016a). edTPA World Language. Assessment Handbook. Stanford: Stanford UP. Print.

. (2016b). "Understanding Rubric Level Progressions: World Language edTPA Fall 2016." Web. 17 Jan. 2017.

. (2016c). "edTPA Guidelines for Acceptable Candidate Support." Revised September 2016. Web. 12 Jun. 2017.

Swanson, Peter B. (2008). "Efficacy and Interest Profile of Foreign Language Teachers During a Time of Critical Shortage." NECTFL Review 62: 55-74. Print.

_ . (2012). "Second/Foreign Language Teacher Efficacy: Multiple Factors and Their Relation to Professional Attrition." Canadian Modern Language Review 68.1: 78-101. Print.

Troyan, Francis J., and Carolyn S. Kaplan. (2015). "The Functions of Reflection in High-stakes Assessment of World Language Teacher Candidates.” Foreign Language Annals 48.3: 372-93. Print.

Wiggins, Grant P., and Jay McTighe. (2005). Understanding by Design. Alexandria: Association for Supervision and Curriculum Development. Print. 